\title{
Effect of Artificial Intelligence-Based Application on Saudi Preparatory -Year Students' EFL Speaking Skills at Albaha University
}

Dr. Mohammed Khalaf Ismail Makhlouf

Lecturer of TEFL, Albaha University, Preparatory year

English Language Center, Saudi Arabia

Received: January 1, 2021 Accepted: June 20, 2021 Published: June 22, 2021

doi:10.5296/ijele.v9i2.18782 URL: https://doi.org/10.5296/ijele.v9i2.18782

\begin{abstract}
This study aimed at investigating the effect of Artificial Intelligence(AI) for developing non-English major students at preparatory year, Albaha University some speaking skills. Two instruments were developed for the purpose of this study; a pre-post-speaking test and a speaking rubric. The participants were 20 engineering students at preparatory-year Albaha University, Saudi Arabia. A speaking pre and posttest, speaking rubric and students' self-reflection were administered. The study followed a quasi-experimental one-group pretest-posttest design. The selected speaking skills were developed through a mobile application [ELSA Speak] based on Artificial Intelligence (AI). The selected speaking sub-skills skills were fluency and accuracy. Findings of the study revealed significant differences in the mean scores of the treatment group on the speaking pretest and posttest in favor of the posttest. The results showed that AI enhanced the students' speaking skills. This study concluded with recommendations pertinent to using artificial intelligence as a tool for teaching speaking skills.
\end{abstract}

Keywords: Accuracy, artificial intelligence (AI), ELSA, fluency, speaking skills 


\section{Introduction}

English is an important language for communication. Speaking is an effective way of expressing oneself, in addition to expressing opinions, ideas, and thoughts. As the world is changing every day, and new technologies have changed the way of communication, teachers have to search for novel ways that motivate students and cope with the new ages.

The Covid-19 pandemic has brought about dramatic changes in education, causing a number of schools to close their doors and opening the way for online learning. English learners spend time and money to improve their language competencies, in particular speaking skills. Governments and educational policymakers found that the best way in time of is to make a shift from traditional teaching to utilizing technology in learning. Bharathy (2013) observes that overall change from the regular instruction methodology of speaking to technology approaches in the educational settings is recommended for improving language skills acquisition with particular reference to speaking skills. Jennings (2019) reported that Artificial Intelligence (AI) programs are one of the best ways for self-learning during the pandemic.

\subsection{Speaking Skill}

Communication helps people achieve their aims, desires through delivering their ideas and feelings. Speaking is the most persuasive way to reach goals. The Speaking skill is an important skill to measure language acquisition. Therefore, learners need an appropriate language to communicate with other people worldwide. In addition, speaking is a productive and demanding language skill along with writing, but it is the quickest means for effective and significant communication with others.

Günes (2014) describes the speaking skill as a method of conveying personal thoughts and feelings into utterance to cover mental concepts. Richards and Rodgers (2014) refers to speaking as an interactive process that enables learners to form the target meaning based on the context in which it occurs and their purpose for communication. They add that speaking is a crucial skill that is completely required for real communication. Consequently, using the function of speaking is connected to success for both individuals and society. Thouësny and Bradley (2011) claimed that speaking English is based on learners' language input regarding their language exposure in an interactive, vivid, and supportive environment in real-life communication. Cetin (2017) and Ari (2018) confirmed that humans learn a language for various purposes of communication to express their knowledge and to exchange information in all their life aspects. People learn a new language mainly to improve their comprehension and speaking skills to communicate with the target environment.

Speaking is a skill which eases the process of communication in any language It is not easy for EFL learners to achieve satisfactory communication and so it is important for them to develop their speaking skills. In this regard, this study investigates two major speaking components: fluency and accuracy of pronunciation, vocabulary, and grammar. 


\subsubsection{Fluency}

Fluency is reflected in speaking with speed and confidence. Bailey (2003) defines fluency as the competence of using the language quickly and confidently, with little hesitations and pauses, etc. Furthermore, Harmer (2015) states that fluency refers to using the content of speech for effective communication. Segalowitz (2010) Segalowitz (2010) divides fluency into three categories. The first category is cognitive fluency (planning and assembling utterances competencies), the second category is utterance fluency (the ability to control pauses and speech rate), and the third category is perceived fluency (the ability of the listener to comprehend the speaker)

Webb, Newton, and Chang (2013) defines fluency as the ability to use many familiar words and expressions. EFL learner needs to comprehend the most used English phrases and expressions for the target situations. They add that teachers should draw students' attention to frequent word sequences through planned speaking activities. On the other hand, Kasap (2005) regards poor fluency creates poor interaction and dissatisfaction of communication between partners of communication as they practice speaking at the same time.

In his study, Zakeri (2014) found a link between shadowing and the fluency of EFL learners' oral performance. Two groups (control group and experimental group) of forty EFL learners of intermediate level participated in the study.

In this study, fluency is defined as the sub-speaking skill, which developed through using AI, to use the language naturally in a meaningful interaction.

\subsubsection{Accuracy}

Achieving accuracy in speaking is not an easy task for EFL learners. Ellis (2005) proposes that speaking accuracy reflects a higher level of thinking for error-free performance and control over the language. Housen and Kuiken (2009) define speaking accuracy as the production of speech without errors. Accuracy is a complex component of speaking skill, as it is the ability to correct language errors. Therefore, Housen and Kuiken consider accuracy as a sign of language proficiency.

According to the International English Language Testing System Handbook (IELTS, 2007), accuracy includes grammar, pronunciation, and vocabulary which reflects the ability of candidates to expand and perform them accurately.

Pronunciation is a very important component of speaking skills. In this respect, Vasbieva, et al. (2016) confirm that Rephrase: EFL learners need to practice appropriate pronunciation of the new words they are trying to master. Pronunciation is a key micro-skill in tackling the communication process. On the other hand, mispronunciation may hinder communication. Giba and Ribes (2011) explain that English pronunciation seems to be a difficult area for EFL learners to master due to its complex phonological system. Besides, some teachers not only neglect to improve this phonological system but also have poor pronunciation.

Another aspect which requires accuracy to improve speaking skill is vocabulary. Recent 
literature (e.g. Schmitt, 2008; Zarei \& Mahmoodzadeh, 2014; Ramezanali, 2017) emphasizes the importance of using accurate vocabulary for constructing successful communication. Using the appropriate vocabulary is a crucial component in learning and teaching the language. Therefore, successful communication depends on the amount of accurate vocabulary used between speaker and listener.

Kontogeorgou and Zafiri (2016) theorize that improving the grammatical structure enhances EFL learners' performance in speaking skills. They stress that teachers should pay great attention to help students to understand grammar in order to participate in meaningful communication. Moreover, they should encourage EFL learners to use a specific point of grammar in everyday communication.

The researcher could operationally define accuracy as the production of language error-free in vocabular, pronunciation and grammar.

In addition to all previously reviewed studies that prove the importance of speaking, other studies revealed that speaking is still a challenging task for students. There are many reasons for these challenges. EFL learners view speaking as a complex skill, which could affect their academic performance negatively and reduce their ability to communicate appropriately. On the other hand, speaking skill is underestimated by many EFL teachers who build their improvement of speaking skill upon memorization and repetition of typical phrases to be used in some situations. To prove these assumptions, the researcher investigates some recent research (e.g. Jdetawy, 2011\& Alhaisoni and Rahman, 2013\& Alhmadi 2014) assert that EFL learners come across some problems in speaking because of the little use of English in real communication. In this respect, McLean (2012) and Roehl et al. (2013) report that speaking is a complex skill in both learning and teaching in EFL contexts.

Traditional classes do not fulfill learners' needs to improve their speaking skills because of the lack of interaction and weak speaking styles of some teachers. Educational Testing Services (2016) highlights that EFL learners deliver less speaking practice than they do in other receptive and productive skills (e.g. reading; writing; and listening). To help EFL learners improve their English-speaking skills, teachers need to increase the amount of communication exposure. Al-Sobhi and Preece (2018) maintain that teaching and learning speaking skill is not only a challenging task for EFL learners but also for teachers, especially for Arabs. As English is spoken worldwide, teachers of English need to utilize new teaching strategies to tackle the difficulty of speaking skills. Elsayad (2020) concludes that EFL learners have a problem with speaking skills, as they could not express themselves in English.

In light of previous research that reveals some problems in speaking skill not only in students' performance but also in the teaching methods. As a result of COVID-19 which prevented face-to-face interaction, this research, examines using a kind of technology based on AI to increase the time of interaction.

\subsection{Artificial Intelligence}

Information and communication technology (ICT) has become one of the basic blocks of modern society. Many countries now regard understanding ICT and mastering the basic skills 
and concepts of ICT as the core of education, alongside reading, writing, and numeracy. Now, all countries seek to prepare their learners to face the needs of modern life. In fact, the Covid-19 has directly impacted the use of technology in communication for both social interaction and education. One of the most prominent technology applications is AI. Ahmadi (2018) asserts that the utilization of new technologies (i.e., AI) has become an essential part of the teaching and training process. Such technology could facilitate and improve English language learning. Karkera and (2018) and Yoestara and Putri (2019) confirm that before the widespread use of AI has become widely- used, learners used other computerized media to enhance their language skills such as radio apps, youtube, and podcasts. AI has added more value to these media, for instance, self-correction and interaction with human-like native speakers (humanoids). Aldosari (2020) describes AI as a programmed system aimed at simulation and creating smart applications whether on computers or smartphones to achieve many tasks instead of humans. Currently, AI is characterized as an edutainment or educational entertainment.

Akerkar (2014) and Ginsenberg (2012) present artificial intelligence as machines that could make and report educational and intelligent decisions similar to those of humans. Kim (2018) assures that using artificial intelligence tools in classrooms is a successful key to develop oral skills (listening and speaking), because of the accurate assessment and updated features of AI applications. Malik, Tayal, and Vij, (2019) state that Artificial Intelligence (AI) has made a great a tremendous contribution to the educational field. AI It has the advantage of helping both the teachers and the students to develop their teaching and learning skills. It is also the backbone of all the neuro-linguistic programming (NLP) enabled tutoring systems. Furthermore, it plays a significant role in developing the qualities of self-reflection, and increasing students' awareness of questions to generate creative answers.

In the same context, Fryer and Carpenter (2006) assume that AI could help improve many language-classroom practices. It offers an opportunity to practice English with a frequent native speaker to master English. Such communication could overcome the many problems ranging from shyness or a limited-time opportunity of communication to weak feedback or limited use of the target language. In their study, Zou et al. (2020) explored university students' attitudes towards the potential of AI assisted mobile Apps to foster speaking skills in English for academic purposes (EAP) courses in higher education. The results showed that students preferred to use AI applications to develop their speaking ability. AI-supported feedback was an encouraging point for students to enhance their speaking skills. In short, AI is a great source of providing more motivation and opportunities for communication interaction to enhance speaking skills. Becker and Edalatishams (2019) asserts The application of AI technologies (ESLA) could enhance the level of communication through voice interaction and word error rate for voice-recognition systems.

\section{Problem of the Study}

Considering the researcher's experience as an EFL teacher for 16 years, the related research, and the results of the pilot study, EFL speaking has gained a lot of attention in classrooms but not online, during Coronavirus times. Arafat (2020) has reported that virtual classes is used 
everywhere in Saudi Arabia but there is a gap in research to measure the impact of virtual classes on the development of speaking skills in EFL settings, particularly in Saudi Arabia. Activities that entailed speaking skills were under-evaluated. Furthermore, students struggled with some particular skills such as accuracy and fluency. These poor speaking skills made students uninterested, unenthusiastic, and demotivated to speak well. In the same concern, Hussein (2016) assumes that Saudi students suffer from using outdate strategies to learn the speaking skill. Therefore, students have few opportunities to practice their speaking skills outside classroom to communicate with community members. The primary concern of the present study was to investigate how far AI could promote EFL preparatory year students' speaking skills.

Based on the previous problem statement, the researcher proposes that teaching speaking skills call for adapting technologies such as AI as a medium that may improve their language learning.

\section{Research Questions}

The present study investigated the following main question:

How using AI for EFL speaking in Albaha University English preparatory program contributes to developing English speaking skills of Saudi first-year non-English-major students?

From the previous question, the following questions branch out:

a) What is the effect of using the AI-based App of ELSA on the fluency and accuracy of Saudi first-year non-English major students' EFL speaking in Albaha University English preparatory program?

b) How does using AI-based App. of ELSA contribute to the fluency and accuracy of Saudi first-year non-English major students' EFL speaking in Albaha University English preparatory program?

\section{Hypotheses}

Based on the questions of the study the following hypotheses are formulated

1 -There is a statically significant difference $\leq 0.05$ between the mean scores of the pretest and of the posttest of the treatment group on the overall speaking test in favor of the posttest.

2 -There is a statically significant difference $\leq 0.05$ between the mean scores of the pretest and the posttest of the treatment group on fluency in favor of the posttest.

3-There is a statically significant difference $\leq 0.05$ between the mean scores of the pretest and the posttest of the treatment group on accuracy in favor of the posttest. 
4-The use of the artificial intelligence program has an effect of $\geq 0.05$ on developing some speaking skills among students of non-English majors in the preparatory year at Al-Baha University.

\section{Purpose}

The present study aimed at investigating how far AI could contribute to developing Speaking skills of non- English major students at preparatory year Albaha University.

\section{Significance}

This study is significant because it may help raise students' awareness of harnessing new technology in their EFL learning. It could also help students improve their EFL speaking skills through more authentic and interactive learning environments. Besides, it may provide teachers with insights for teaching EFL speaking with technology. Its implications may offer curriculum developers with alternative technology-based solutions that might help them design more authentic and responsive EFL curricula and instructional strategies.

\section{Delimitations}

The study is confined to:

- English Language Speech Assistant (ELSA) which is an AI-based mobile App used for training students on English pronunciation and accent.

- Preparatory-year students at Engineering college at Albaha university

- Speaking skills appropriate for preparatory-year students at Engineering College at Albaha university (fluency and accuracy).

- quasi-experimental one-group pretest-posttest design

\section{Methodology}

Methodology includes research design, instruments and participants.

\subsection{Research Design}

The study uses a quasi-experimental one-group design. A mixed method research design (quantitative and qualitative methods) was used for data collection.

\subsection{Instrument}

The current study uses two kinds of instruments; referential instruments (e.g. speaking rubric and students' self-reflection) and research instruments (e.g. speaking pre-posttest).

\subsection{Participants}

The participants of the study were 20 Preparatory-year students at Engineering college at Albaha university who study integrated English skills course. 


\section{Macrothink}

\section{AI based Application}

The AI based application (ELSA Speak) aims at developing some of the EFL preparatory-year students' speaking skills. It is based on authentic learning in terms that students speak about an authentic task that they can see in their daily such as food, entertainment, school and daily conversation. ELSA has a simple interface including simple navigation between topics and sounds. Students start with speaking assessment test according to their proficiency level; students can start the course.

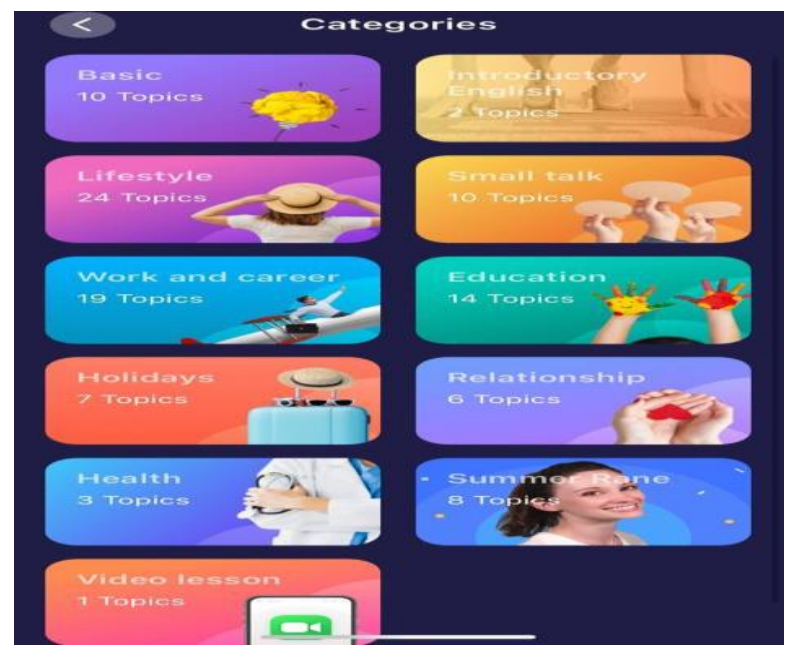

Figure 1. category of topic at beginner level

Figure 1 presents a variety of topic at beginner level which could help students accuracy and fluency.

\section{Pronunciation}

Students can get the feedback through listening to the pronunciation and record themselves, ELSA analyses the recorded voice and provide students with feedback accompanying with a score.

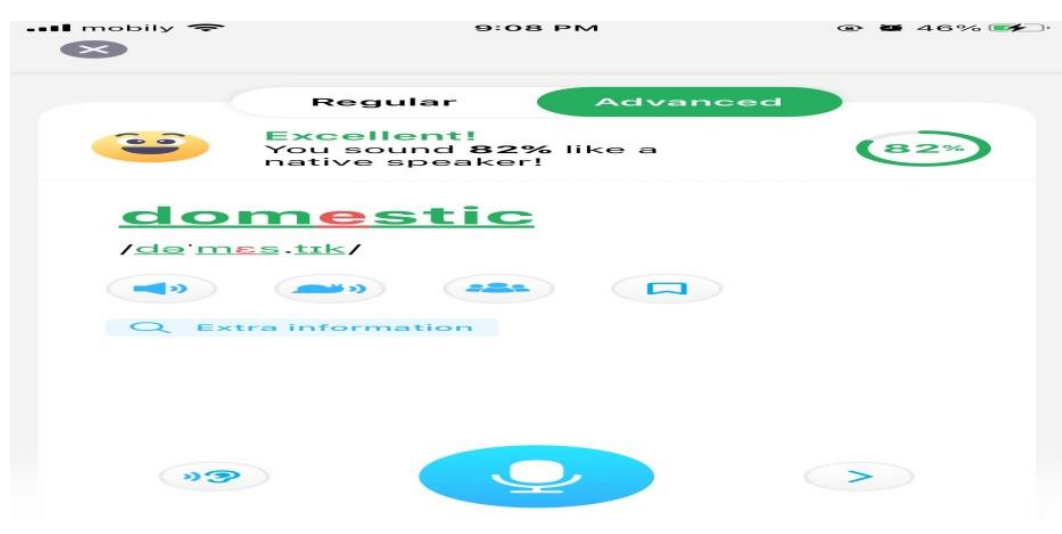

Figure 2. pronunciation score 


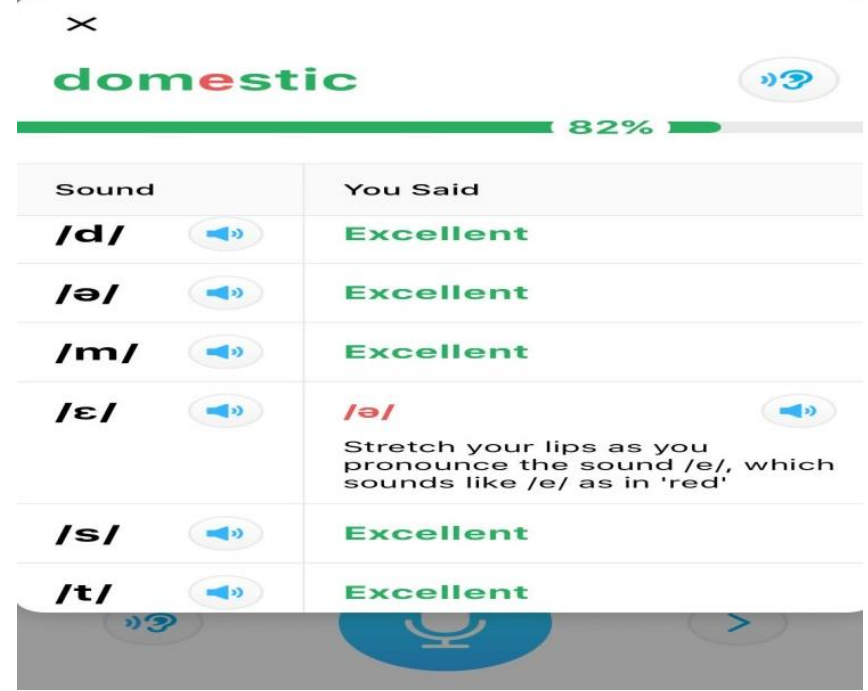

Figure 3. pronunciation feedback

According to figure 2 and 3, students can get their pronunciation score and feedback for words and sentences.

\section{Vocabulary}

ELSA can develop Students' vocabulary through building a bank of words to the related topics.

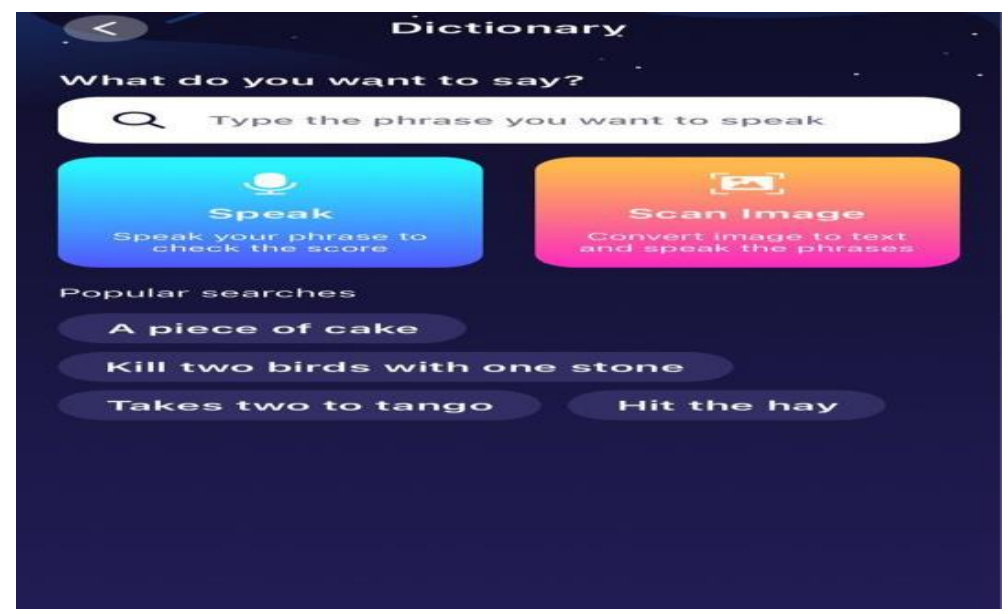

Figure 4. ELSA dictionary

Figure 4 shows that students can build their own vocabulary bank using ELSA dictionary

\section{Grammar}

ELSA provide students with conversations; students have to reply to this conversation in a full sentence. If they missed a word, ELSA give them a feedback that there is a missing word. 


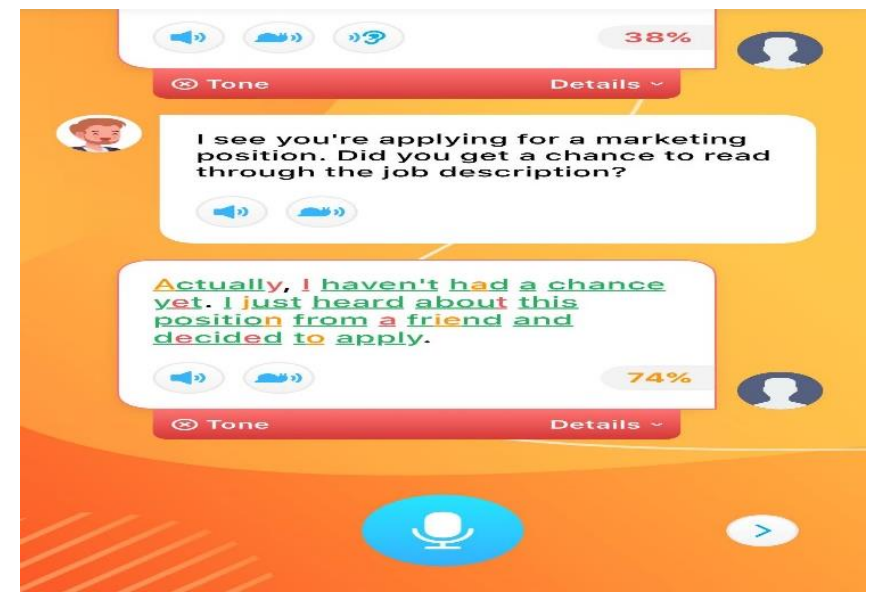

Figure 5. ELSA conversation

Figure 5 shows that ELSA supports students with some conversations based on AI. It could help students to develop their grammar and fluency skill.

\section{Speaking Test}

\subsection{Test Description}

The speaking test included Four questions. They are mainly test speaking. They were similar to the speaking activities in the ELSA application; the items were as follows:

Question 1, students are to look at four sequenced pictures and describe them orally.

Question 2, respond to the question

Question 3, express opinion

Question 4, propose a solution

\subsection{Test Validity}

To examine the validity of the test, the study looked into three types of validity: face validity, internal validity, and construct validity.

\subsection{Face Validity}

To measure test content validity, the first version of the test, which consisted of three questions, was given to eleven EFL professors and school supervisors. They were requested to validate and make necessary changes on the appropriateness of the EFL speaking test content to the proposed speaking skills, selected students' level, and dedicated time. Their suggestions were considered and accommodated on the final version of the EFL speaking test.

\subsection{Internal Validity}

To calculate the internal validity of the speaking pre posttest, the researcher used Pearson statistical formula as follows: 
To determine the internal validity of the test, the correlation coefficient of each sub-skill of the speaking skills was computed with the total score of the test as a whole. These correlations and their statistical significance are shown in Table 1.

Table 1. Internal Validity

\begin{tabular}{llll}
\hline \multirow{2}{*}{ Main Skills } & Sub-Skills & $\begin{array}{l}\text { Correlation } \\
\text { coefficient }\end{array}$ & $P$-value \\
& & & \\
\hline \multirow{3}{*}{ Fluency } & Confidence & .81 & .01 \\
& Content & .84 & .01 \\
& Comprehension & .79 & .01 \\
Accuracy & Vocabulary & .81 & .01 \\
& Grammar & .88 & .01 \\
& Pronunciation & .82 & .01 \\
\hline
\end{tabular}

The statistical findings of Table 1 indicate that speaking sub-skills ranged between .79 and .88 which were statistically significant at .01 level of confidence.

\subsection{Construct Validity}

To calculate the construct validity of the speaking pre-and posttests, the study used Pearson's statistical formula as follows:

To determine the construct validity of the test, the correlation coefficient of the total score of the main skills (fluency -accuracy). These correlations and their statistical significance are shown in Table 2.

Table 2. Construct Validity

\begin{tabular}{lll}
\hline Main Skills & Correlation coefficient & $P$-value \\
\hline Fluency & 0.91 & 0.01 \\
Accuracy & 0.92 & 0.01 \\
\hline
\end{tabular}

The statistical findings of table 2 indicate that speaking skills ranged between .91 and .92 which were statistically significant at .01 level of confidence. These findings reveal a high internal consistency of the test. Hence, the validity of the pre/ post EFL reading and writing test was proven.

\section{Test Reliability}

The researcher used Alpha Cronbach's Coefficient formula to examine the reliability of the test, with specific reference to its internal consistency. Table 3 shows the Cronbach's Coefficient Alpha scores of the different skills of the test. 


\section{Macrothink}

Table 3. Test reliability

\begin{tabular}{lll}
\hline Main Skills & Sub-skills & Cronbach's Alpha \\
\hline Fluency & 3 & .73 \\
Accuracy & 3 & .78 \\
Speaking & 6 & .85 \\
\hline
\end{tabular}

Table 3 shows that the correlation coefficient ranged from .73 and .78 for each skill and .85 for speaking as a whole which indicates a positive correlation between the scores at .01 level. This indicates that there was a strong correlation between the scores of the reading and writing skills test.

\section{Students' Self-reflection}

The researcher posed some reflection questions to know more about students' opinions about using AI on developing speaking. The students' self-reflection was submitted to some jury members specialized in TEFL. The results of Students' self-reflection were discussed in the discussion section.

\section{Statistical Analysis Results}

\subsection{Results of the First Hypothesis}

The first hypothesis stated that there is a statically significant difference $\leq 0.05$ between the mean scores of the pretest and of the posttest of the treatment group on the overall speaking test in favor of the posttest. To test this hypothesis, the researcher Compared the mean score of the pre-posttest of speaking skills. Table 4 below shows these differences.

Table 4. Comparing the mean score of the pre-posttest of speaking skills

\begin{tabular}{lll}
\hline Test & Mean & SD \\
\hline Pre-test & 6.20 & 2.02 \\
Post-test & 16.50 & 1.85 \\
\hline
\end{tabular}

Table 5 indicates that the mean score of the pre-test was 6.20 and the post-test was 16.50 respectively.

To show the differences of the pre-posttest, the researcher used the Wilcoxon Signed Ranks Test. Table 5 below shows these differences.

Table 5. Establishing the differences of the pre-posttest

\begin{tabular}{|c|c|c|c|c|c|c|c|}
\hline & & Ranks types & $\mathrm{N}$ & $\begin{array}{l}\text { Mean } \\
\text { Rank }\end{array}$ & $\begin{array}{l}\text { Sum } \\
\text { Ranks }\end{array}$ & $\mathrm{f}_{Z}$ & $P$-value \\
\hline \multirow{4}{*}{$\begin{array}{l}\text { Speaking } \\
\text { skills test }\end{array}$} & \multirow{4}{*}{$\begin{array}{c}\text { Post } \\
- \\
\text { Pre }\end{array}$} & Negative Ranks & & .0 & .0 & \multirow{4}{*}{3.94} & \multirow{4}{*}{.001} \\
\hline & & Positive Ranks & 20 & 10.5 & 210.0 & & \\
\hline & & Ties & 0 & & & & \\
\hline & & Total & 20 & & & & \\
\hline
\end{tabular}

Table 5 illustrates that there is a statically significant difference $\leq 0.05$ between the mean 
scores of the pretest and the posttest of the treatment group on the overall speaking test in favor of the posttest. The $\mathrm{Z}$ value was 3.94 at a which indicates statistically significant differences between the pre-posttest in favor of posttest at .001 level. Table 5 shows the mean score of the pre-posttest of speaking skills.

\subsection{Results of the Second Hypothesis}

The second hypothesis stated that there is a statically significant difference $\leq 0.05$ between the mean scores of the pretest and the posttest of the treatment group on fluency in favor of the posttest. To test this hypothesis, the researcher used the Wilcoxon Signed Ranks Test. Table 6 below shows these differences.

Table 6. Establishing the difference between the mean scores of the pretest and the posttest of the treatment group on fluency and its sub-skills in favor of the posttest

\begin{tabular}{|c|c|c|c|c|}
\hline Sub-skills & Ranks types & $\mathrm{N}$ & $\begin{array}{l}\text { Mean } \\
\text { Rank }\end{array}$ & $\begin{array}{l}\text { Sum of } \\
\text { Ranks }\end{array}$ \\
\hline
\end{tabular}

\begin{tabular}{|c|c|c|c|c|c|c|c|}
\hline \multirow{4}{*}{ Confidence } & \multirow{4}{*}{$\begin{array}{c}\text { Post } \\
\text { - } \\
\text { Pre }\end{array}$} & Negative Ranks & 0 & .0 & .0 & \multirow{4}{*}{3.95} & \multirow{4}{*}{.001} \\
\hline & & Positive Ranks & 19 & 10.0 & 190.0 & & \\
\hline & & Ties & 1 & & & & \\
\hline & & Total & 20 & & & & \\
\hline \multirow{4}{*}{ Content } & \multirow{4}{*}{$\begin{array}{l}\text { Post } \\
\text { - } \\
\text { Pre }\end{array}$} & Negative Ranks & 0 & .0 & .0 & \multirow{4}{*}{3.86} & \multirow{4}{*}{.001} \\
\hline & & Positive Ranks & 18 & 9.5 & 171.0 & & \\
\hline & & Ties & 2 & & & & \\
\hline & & Total & 20 & & & & \\
\hline \multirow{4}{*}{ Comprehension } & \multirow{4}{*}{$\begin{array}{l}\text { Post } \\
\text { - } \\
\text { Pre }\end{array}$} & Negative Ranks & 0 & 0.0 & 0.0 & \multirow{4}{*}{4.06} & \multirow{4}{*}{.001} \\
\hline & & Positive Ranks & 20 & 10.5 & 210.0 & & \\
\hline & & Ties & 0 & & & & \\
\hline & & Total & 20 & & & & \\
\hline \multirow{4}{*}{$\begin{array}{l}\text { Fluency } \\
\text { (main skill) }\end{array}$} & \multirow{4}{*}{$\begin{array}{c}\text { Post } \\
\text { - } \\
\text { Pre }\end{array}$} & Negative Ranks & 0 & .0 & 0.0 & \multirow{4}{*}{3.95} & \multirow{4}{*}{.001} \\
\hline & & Positive Ranks & 20 & & 210.0 & & \\
\hline & & Ties & 0 & & & & \\
\hline & & Total & 20 & & & & \\
\hline
\end{tabular}

Table 6 illustrates that there is a statically significant difference $\leq 0.05$ between the mean scores of the pretest and the posttest of the treatment group on fluency skill and its sub-skills in favor of the posttest. The $\mathrm{z}$ value for fluency was 3.95and for sub-skills 3.95 ، 3.86 ، 4.06 respectively at a .001 level which indicates statistically significant in fluency skill and its sub-skills between the pre-posttest in favor of posttest. Table 7 below explain the mean score between the pre-posttest application of fluency and its sub-skills 
Table 7. The mean score between the pre-posttest application of fluency and its sub-skills

\begin{tabular}{rrrr}
\hline Skills & Test & Mean & SD \\
\hline \multirow{2}{*}{ Confidence } & Pretest & 1.10 & 0.45 \\
& Posttest & 2.60 & 0.50 \\
Content & Pretest & 0.95 & 0.69 \\
& Posttest & 2.75 & 0.55 \\
Comprehension & Pretest & 0.90 & 0.45 \\
& Posttest & 2.65 & 0.59 \\
Fluency & Pretest & 2.95 & 1.15 \\
(Main skill) & Posttest & 8.00 & 1.08 \\
\hline
\end{tabular}

Table 7 reports the mean score in fluency skills was 2.95 in the pre-test and 8.0 in the posttest. The mean scores of fluency's sub-skills were 1.10 ، 95 ، .90 in pre-test and 2.60 ، 2.75 ، 2.65 in posttest respectively. This indicates that the treatment group outperformed in the post-test than the pre-test.

\subsection{Results of the Third Hypothesis}

The third hypothesis stated that there is a statically significant difference $\leq 0.05$ between the mean scores of the pretest and the posttest of the treatment group on accuracy in favor of the posttest". To test this hypothesis, the researcher used the Wilcoxon Signed Ranks Test. Table 8 below shows these differences.

Table 8. Comparing the mean score between the pre-posttest application of accuracy and its sub-skills

\begin{tabular}{|c|c|c|c|c|c|c|c|}
\hline Sub-skills & & Ranks types & $\mathrm{N}$ & $\begin{array}{l}\text { Mean } \\
\text { Rank }\end{array}$ & $\begin{array}{l}\text { Sum } \\
\text { of } \\
\text { Ranks }\end{array}$ & $\mathrm{Z}$ & P-value \\
\hline \multirow{4}{*}{ Vocabulary } & \multirow{4}{*}{$\begin{array}{l}\text { Post } \\
\text { - } \\
\text { Pre }\end{array}$} & Negative Ranks & 0 & 0.0 & 0.0 & \multirow{4}{*}{4.03} & \multirow{4}{*}{0.001} \\
\hline & & Positive Ranks & 20 & 10.5 & 210.0 & & \\
\hline & & Ties & 0 & & & & \\
\hline & & Total & 20 & & & & \\
\hline \multirow{4}{*}{ Grammar } & \multirow{4}{*}{$\begin{array}{l}\text { Post } \\
\text { - } \\
\text { Pre }\end{array}$} & Negative Ranks & 0 & 0.0 & 0.0 & \multirow{4}{*}{4.01} & \multirow{4}{*}{0.001} \\
\hline & & Positive Ranks & 20 & 10.5 & 210.0 & & \\
\hline & & Ties & 0 & & & & \\
\hline & & Total & 20 & & & & \\
\hline \multirow{4}{*}{ Pronunciation } & \multirow{4}{*}{$\begin{array}{l}\text { Post } \\
- \\
\text { Pre }\end{array}$} & Negative Ranks & 0 & 0.0 & 0.0 & \multirow{4}{*}{4.09} & \multirow{4}{*}{0.001} \\
\hline & & Positive Ranks & 20 & 10.5 & 210.0 & & \\
\hline & & Ties & 0 & & & & \\
\hline & & Total & 20 & & & & \\
\hline \multirow{4}{*}{$\begin{array}{l}\text { Accuracy } \\
\text { (Main skill) }\end{array}$} & \multirow{4}{*}{$\begin{array}{l}\text { Post } \\
- \\
\text { Pre }\end{array}$} & Negative Ranks & 0 & 0.0 & 0.0 & \multirow{4}{*}{3.95} & \multirow{4}{*}{0.001} \\
\hline & & Positive Ranks & 20 & 10.5 & 210.0 & & \\
\hline & & Ties & 0 & & & & \\
\hline & & Total & 20 & & & & \\
\hline
\end{tabular}




\section{Ml Macrothink}

Table 8 shows there is a statically significant difference $\leq .05$ between the mean scores of the pretest and the posttest of the treatment group on accuracy skill and its sub-skills in favor of the posttest. The $\mathrm{z}$ value for accuracy was 3.95 and for sub-skills 4.03 ، 4.01 ، 4.09 respectively .001level which indicates statistically significant on accuracy skill and its sub-skills between the pre-posttest in favor of posttest. Table 9 below presents the mean score between the pre-posttest application of accuracy skill and its sub-skills.

Table 9. The mean score between the pre-posttest application of accuracy skill and its sub-skills

\begin{tabular}{llll}
\hline Sub-Skills & Test & Mean & SD \\
& Pretest & 1.20 & 0.41 \\
Vocabulary & Posttest & 2.85 & 0.59 \\
& Pretest & 1.45 & 0.60 \\
Grammar & Posttest & 3.05 & 0.60 \\
& Pretest & 0.60 & 0.50 \\
Pronunciation & Posttest & 2.60 & 0.50 \\
accuracy & Pretest & 3.25 & 1.12 \\
(Main skill) & Posttest & 8.50 & 1.00 \\
\hline
\end{tabular}

Table 9 reports the mean score on accuracy skill was 3.25 in the pre-test and 8.50 in the posttest. The mean scores of accuracy's sub-skills were 1.10 ، $1.25 \cdot 0.60$ in pre-test and 2.85

3.05 ، 2.60 in posttest respectively. These results confirm that the treatment group outperformed the accuracy skill in the post-test than in the pre-test.

\subsection{Results of the Fourth Hypothesis}

The fourth hypothesis stated that the use of the artificial intelligence program has an effect of $\geq .05$ on developing some speaking skills among students of non-English majors in the preparatory year at Al-Baha University ". In order to test this hypothesis, the researcher used the effect size. Cohen(1988) explains that the low effect is at .1, medium at .3, and large at .5. Table 10 below shows the results of the effect size.

Table 10. The effect of the use of the artificial intelligence program on developing some speaking skills among the treatment group

\begin{tabular}{lllc}
\hline Main Skills & $Z$ & $\mathrm{~N}$ & Effect size \\
Fluency & 3.947 & 20 & .883 \\
Accuracy & 3.953 & 20 & .884 \\
Speaking & 3.936 & 20 & .880 \\
\hline
\end{tabular}

According to the results of Table 10, there is a large effect of the use of artificial intelligence program on developing some speaking skills among treatment group the effect size of fluency was .883 and accuracy was .880 . This indicates a large effect of the program. The following figure 1 shows the size effect. 
Figure 1. size effect of using the artificial intelligence program on developing some speaking skills among the treatment group.

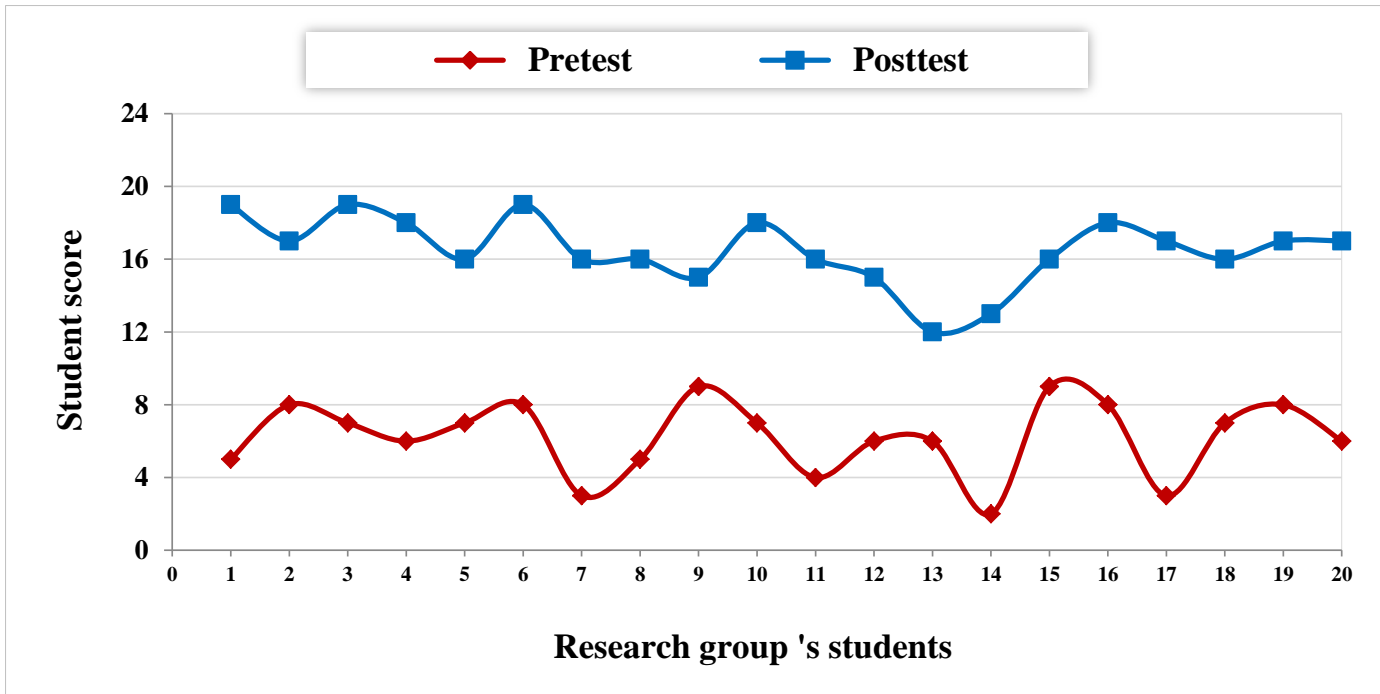

\section{Discussion of the Results of the Study}

The findings of the study showed that the AI-based App of ELSA was effective in helping the non-English major students improve their EFL speaking skills in the preparatory year at Albaha University. The results of the speaking test indicated that there was a significant difference among scores of the pre-posttest of the treatment group in favor of the post-test. The treatment group had more improvement in their scores in the post-test than they did in the pretest. Such a finding is consistent with previous research (e.g., Yin et al., 2010) that the AI-based Software/App could help improve EFL students' speaking ability.

The findings of students' self-reflection also showed that AI has the benefits of an increasing sense of personal responsibility for learning and a realization of individual differences. Students expressed that feedback was one of the fundamental results of this research. It helped them improve their speaking skills and enabled them to produce oral texts with fewer errors and more clarity. Receiving AI feedback improved students' linguistic knowledge and allowed them to learn more about the skills of speaking skills. As such, empirical and theoretical perspective has supported the use of AI feedback in EFL speaking classes. These results coincide with Malik, Tayal, and Vij (2019).

Students also reported that they liked to use the application more times a day. This frequent use refers to their motivation for learning and improving their speaking skills. In addition, Students in the present research were inspired to utilize artificial intelligence in speaking skills for different reasons. First, students had a great desire to use mobile applications; thus, artificial intelligence provided the students with the chance to learn through a model this like. Second, the application feedback was really motivating for students to enhance their speaking skills as the application provide them with feedback about their speaking and how to pronounce well. In the record of the students' reflection log, students told that they used ELSA Speaking application most of their free time even after finishing the treatment. These results are congruent with the previous studies in the field of EFL/ ESL such as (Ordinas, 
Fischer\& Waast-Richard ,2005 and Cartwright, (2016.) that prove motivation as one of the most important findings of utilizing artificial intelligence for the research.

A safe speaking environment was one of the encouraging results of this study Students learned from their own mistakes. Students mentioned that when they were revising the program feedback, they corrected a lot of their mistakes. AI program increased students' self-reflection. Some students said that the AI program allowed them to organize and convey their thoughts quickly. Another student reported that using the AI program helped him to reflect on his speaking skill. This result is in line with Malik, Tayal, and Vij, (2019).

In brief, the AI program helped the beginning students build their confidence in speaking English. AI program could positively affect students' speaking ability due to the friendly environment which is non-threatening to students as they felt free to speak what they thought about. In addition, the AI program activities were flexible and appropriate as they took into account individual speaking differences among students and students could speak according to their level.

Flexibility is another positive result of this study results of Seol, Rolfes , Chung et al (2019) agrees with the recent study that AI provided Students free time and space. Students were able to access the application from any mobile with internet access; free time and place to practice speaking was a positive aspect of speaking.

\section{Conclusions}

Drawing upon the results of the speaking test and students' self-reflection in this study, a plethora of insightful implications and substantial gains could be concluded as it was apparent that there was a gap in research concerning speaking using Artificial Intelligence (AI) in teaching and learning. The current study bridged this gap by investigating the effect of Artificial Intelligence (AI) on developing speaking skills; namely, fluency and accuracy. To achieve this purpose, Artificial Intelligence (AI) based program was designed and implemented. Findings indicated that Artificial Intelligence (AI) had significantly developed the learners' speaking skills and improved autonomous learning. These results of the program cannot be attributed only to the Artificial Intelligence (AI) program. This success can be partially attributed as well, to the strategies and activities used during experimentation and also to the systematic design of the program. It was obvious that Artificial Intelligence (AI) based program provided students with a better learning environment that was positively reflected on their speaking performance.

The research findings show that using Artificial Intelligence (AI) motivated students to speak through working on authentic tasks. Using Artificial Intelligence (AI) provided great opportunities for low and intermediate achievers to get involved with high achievers and learn from them. Therefore, shy students and low-achievers became more motivated to participate and interact. In addition, learning became more learner-centered as Artificial Intelligence (AI) helped participants build a sense of leadership and ownership of their learning.

Finally, it could be concluded that this type of Artificial Intelligence (AI) developed EFL 
students' speaking skills and motivated them for language learning. More emphasis should be placed in forthcoming research on the previously treated aspects of Artificial Intelligence (AI) (e.g., using authentic tasks; online feedback; transferring of knowledge) to engage students more effectively and achieve better learning outcomes.

\section{References}

Akerkar, R. (2014). Introduction to artificial intelligence (2nd ed.). Delhi: PHI Learning.

Aldosari, S. A. (2020). The future of higher education in the light of artificial intelligence transformations. International Journal of Higher Education, 9(3), 145. https://doi.org/10.5430/ijhe.v9n3p145

Alhaisoni, M., \& Rahman M. (2013). Teaching English in Saudi Arabia: Prospects and Challenges. Retrieved on 18th Jun. 2020 from http://www.journals.savap.org.pk/issue.html

Alhmadi, N. S. (2014a). English speaking learning barriers in Saudi Arabia: A case study of Tibah University. Arab World English Journal, 5(2), 38-53.

Al-Sobhi, B. M., \& Preece, A. S. (2018). Teaching English speaking skills to the Arab students in the Saudi school in Kuala Lumpur: Problems and solutions. International Journal of Education and Literacy Studies, 6(1), 1. https://doi.org/10.7575/aiac.ijels.v.6n.1p.1

Arafat, H. (2020). The Effect of Virtual classes on Saudi EFL Students' Speaking Skills. International Journal of Linguistics, Literature and Translation (IJLLT), 3(4), 175-204. https://doi.org/10.32996/ijllt.2020.3.4.18

Ari, G. (2018). Speech training. M. Durmus and A. Okur (Eds.), In the Handbook of Teaching Turkish as a Foreign Language (pp. 277-293). Ankara: Grafiker Publishing.

Bailey, K. (2003). Speaking. In D. Nunan (Ed.), Practical English language teaching (pp. 47-66). McGraw-Hill Education. Retrieved from http://www.princeton.edu/ pia/TEFL/Nunan\%20Chapter\%203\%20tefl.pdf

Bharathy, M. (2013). Effectiveness of roleplay in enhancing speaking skills of tertiary level learners. IOSR Journal of Humanities And Social Science, 13(1), 17-19. https://doi.org/10.9790/0837-1311719

Becker, K., \& Edalatishams, I. (2019). ELSA Speak - Accent Reduction [Review]. In J. Levis, C. Nagle, \& E. Todey (Eds.), Proceedings of the 10th Pronunciation in Second Language Learning and Teaching Conference, ISSN 2380-9566, Ames, IA, September 2018 (pp. XX-XX). Ames, IA: Iowa State University.

Cartwright, A. (2016). invisible Design Co-Designing with Machines. Retrieved from http://airbnb.design/invisibledesign/?utm_source=CB+Insights+Newsletter\&utm_campa ign=dd8d7f7b9dTuesNL_6_28_2016\&utm_medium=email\&utm_term=0_9dc0513989dd8d7f7b9d-870480370rdinas. 


\section{Ml Macrothink}

Cetin, D. (2017). Language skills - expression (speech and writing skills)] H. Develi and others (Eds.), In the Handbook on Teaching Turkish as a Applied Foreign Language (pp. 359-424). Istanbul: Kesit Publishing

De Laat, M., Joksimovic, S. and Ifenthaler, D. (2020), "Artificial intelligence, real-time feedback and workplace learning analytics to support in situ complex problem-solving: a commentary", International Journal of Information and Learning Technology, Vol. 37 No. 5, pp. 26277. https://doi.org/10.1108/IJILT-03-2020-0026

Ellis, R. (2005). Planning and task-based performance: Theory and research. In R. Ellis (Ed.), Planning and task performance in a second language (pp. 3-34). John Benjamins Publishing. https://doi.org/10.1075/11lt.11.03ell

Elsayad, A. E. (2020). Effects of a program of interactive tasks designed according to IDLS model in developing English speaking skills and motivation to speak among preparatory school students [Doctoral dissertation, Tanta University]. EULC Repository. http://main.eulc.edu.eg/eulc_v5/Libraries/Thesis/BrowseThesisPages.aspx?fn=PublicDr awThesis\&BibID=12626585

Fryer, L., \& Carpenter, R. (2006) Bots as Language Learning Tools. Language Learning \& Technology, 10(3), 8-14.

G. Yin, G.J. Luo,J. and Yuan,B. (2010). "Utilizing Text-to-Speech to Assist Bilingual Teaching," 2010 Second International Workshop on Education Technology and Computer Science, Wuhan, 2010, pp. 594-597, https://doi.org/10.1109/ETCS.2010.254.

Giba, J., \& Ribes, R. (2011). Preparing and delivering scientific presentations: A complete guide for international medical scientists. Springer Science \& Business Media.

Ginsberg, M. (2012). Essentials of artificial intelligence. Morgan Kaufmann Publishers Inc.

Günes, F. (2014). Speech teaching approaches and models. Bartin University Journal of Education Faculty, 3(1), 1-27. https://media.proquest.com/media/pq/classic/doc/3340800061/fmt/pi/rep/NONE?_s=Fq NsseMHjPDqZCqN\%2F9gyJ5gCiJo\%3D

Harmer, J. (2015). The practice of English language teaching (5th ed.). Harlow, UK: Pearson Longman.

Housen, A., \& Kuiken, F. (2009). Complexity, accuracy, and fluency in second language acquisition. Applied linguistics, 30(4), 461-473. https://doi.org/10.1093/applin/amp048

Hussein, T. (2016). The Effectiveness of Using Blackboard in Improving the English Listening and Speaking Skills of the Female Students at the University of Hail. Advances in Social Sciences Research Journal, 3(12), 81-93.

International English language testing system (IELTS). (2007). IELTS handbook: 2007. Cambridge University, ESOL Examinations

J. B., Fischer, V., \& Waast-Richard, C. (2005). Multilingual models in the IBM bilingual 
text-to-speech systems. In 9th European Conference on Speech Communication and Technology (pp. 1485-1488).

Jdetawy, L. F. (2011). Problems encountered by Arab EFL learners. Language in India, 11(3), 19-27. http://www.languageinindia.com/march2011/arabicefllearnersfinal.pdf

Jennings, C. (2019). Artificial intelligence: Rise of the Lightspeed learners. Rowman \& Littlefield.

Karkera, S., \& Chamundeshawari, C. (2018). YouTube: A teaching tool to improve listening skills. International Journal of Creative Research Thoughts (IJCRT), 6(2), 1311-1316. https://ijcrt.org/papers/IJCRT1813041.pdf

Kasap, B. (2005). The effectiveness of task-based instruction in the improvement of learners' speaking skills [Master's thesis, Bulkint University]. BU Repository. http://repository.bilkent.edu.tr/handle/11693/29652

Kim, J. (2018, November 14). Artificial Intelligence and Retention: The future of persistence in the age of "narrow AI," or deep learning. Inside Higher Ed. https://www.insidehighered.com/digital-learning/blogs/technology-and-learning/artificia 1-intelligence-and-retention

Kontogeorgou, K., \& Zafiri, M. (2016). Using grammar to enhance speaking. Proceedings of the 5th Virtual International Conference on Advanced Research in Scientific Areas (1). ARSA. https://doi.org/10.18638/arsa.2016.5.1.838

Malik, G., Tayal, D. K., \& Vij, S. (2019). An analysis of the role of artificial intelligence in education and teaching. In P. Sa, S. Bakshi, I. Hatzilygeroudis, \& M. Sahoo (Eds.), Recent findings in intelligent computing techniques: Proceedings of the 5th ICACNI 2017 (Vol. 1, pp. 407-417). Springer. https://doi.org/10.1007/978-981-10-8639-7_42

McLean, A. C. (2012). Destroying the teacher: The need for learner-centered teaching. English Teaching Forum, 50(1), 32-35. https://eric.ed.gov/?id=EJ971240

Mukhallafi, T. R. (2020). Using artificial intelligence for developing English language teaching/Learning: An analytical study from University students' perspective. International Journal of English Linguistics, $10(6), \quad 40$. https://doi.org/10.5539/ijel.v10n6p40

Nordrum, A. (2017, January 17). CES 2017: The year of voice recognition. IEEE Spectrum. https://spectrum.ieee.org/tech-talk/consumer-electronics/gadgets/ces-2017-the-year-of-v oice-recognition

Qing. Z. (2013) A Brief Analysis of the Feasible Application of Artificial Intelligence in College English Teaching [J]. Intelligence, 2018 (31): 67.

Ramezanali, N. (2017). Short and long-term vocabulary learning and retention through multimedia glossing: A mixed methods research [Doctoral dissertation]. Electronic Thesis and Dissertation Repository. https://ir.lib.uwo.ca/etd/4588 
Richards, J. C., \& Rodgers, T. S. (2014). Approaches and methods in language teaching (3rd ed.). Cambridge University Press.

Roehl, A., Reddy, S. L., \& Shannon, G. J. (2013). The flipped classroom: An opportunity to engage millennial students through active learning strategies. Journal of Family \& Consumer Sciences, 105(2), 44-49. https://doi.org/10.14307/jfcs105.2.12

Schmitt, N. (2008). Review article: Instructed second language vocabulary learning. Language Teaching Research, 329-363. https://doi.org/10.1177/1362168808089921

Segalowitz, N. (2010). Cognitive bases of second language fluency. Routledge.

Seol ,H., Rolfes M., Chung W, et al (2019). Expert artificial intelligence-based natural language processing characterises childhood asthma. BMJ Open Resp Res 2020;7:e000524. https://doi.org/10.1136/ bmjresp--000524

Thouësny, S., \& Bradley, L. (2011). Introduction on views of emergent researchers in L2 teaching and learning with technology. Second Language Teaching and Learning with Technology: Views of Emergent Researchers, 1-8. https://doi.org/10.14705/rpnet.2011.000003

Ulas, A. H. (2008). Effects of creative, educational drama activities on developing oral skills in primary school children. American Journal of Applied Sciences, 5(7), 876-880.

Vasbieva, D. G., Klimova, I. I., Agibalova, E. L., Karzhanova, N. V., \& Bírová, J. (2016). Enhancement of students' vocabulary learning through a blended learning approach. International Electronic Journal of Mathematics Education, 11(5), 1195-1203. https://www.iejme.com/article/enhancement-of-students-vocabulary-learning-through-ablended-learning-approach

Webb, S., Newton, J., \& Chang, A. (2013). Incidental learning of collocation. Language Learning, 63(1), 91-120. https://doi.org/10.1111/j.1467-9922.2012.00729.x

Willardson, D. (2014). The effectiveness of computer-enhanced shadowing and tracking pronunciation exercises for intermediate level foreign language learners. Master's thesis, Brigham Young University, Provo, Utah, US.

Yoestara, M., \& Putri, Z. (2019). Podcast: An alternative way to improve EFL students' listening and speaking performance. Englisia Journal, 6(1), 15. https://doi.org/10.22373/ej.v6i1.3805

Zakeri, E. (2014). Post method era: Amalgamation of methods, a real example. International Journal of Language Learning and Applied Linguistics World, 5(2), 523-529.

Zarei, A. A., \& Mahmoodzadeh, P. (2014). The effect of multimedia glosses on L2 reading comprehension and vocabulary production. Journal of English Language and Literature, 1(1), 01-07. https://doi.org/10.17722/jell.v1i1.1

Zou, B., Liviero, S., Hao, M., \& Wei, C. (2020). Artificial intelligence technology for EAP 
speaking skills: Student perceptions of opportunities and challenges. In M. R. Freiermuth \& N. Zarrinabadi (Eds.), Technology and the psychology of second language learners and users (pp. 433-463). Palgrave Macmillan. https://doi.org/10.1007/978-3-030-34212-8_17

\section{Copyright Disclaimer}

Copyright for this article is retained by the author(s), with first publication rights granted to the journal.

This is an open-access article distributed under the terms and conditions of the Creative Commons Attribution license (http://creativecommons.org/licenses/by/4.0/). 